\title{
Catheter Ablation of Atrial Tachycardias After Mitral Valve Surgery
}

\author{
Youssef Jalloul ${ }^{1}$ and Marwan Refaat ${ }^{1}$ \\ ${ }^{1}$ American University of Beirut Medical Center
}

July 7, 2020

\section{Hosted file}

JCE.docx available at https://authorea.com/users/317504/articles/467759-catheter-ablationof-atrial-tachycardias-after-mitral-valve-surgery 